\title{
Prevotella ruminicola
}

National Cancer Institute

\section{Source}

National Cancer Institute. Prevotella ruminicola. NCI Thesaurus. Code C86677.

A species of obligately anaerobic, Gram-negative, rod shaped bacteria assigned to the phylum Bacteroidetes. This species is nonmotile, non-spore forming, nonpigmented, rhamnose, sucrose, esculin hydrolysis, beta- $\mathrm{N}$-acetyl-glucosaminidase, and alphafucosidase positive, but indole and glycine aminopeptidase negative. P. ruminicola is commonly found in the rumen and hindgut of cattle and sheep where it aids in digesting protein and carbohydrate food sources, as well as to prevent bovine rumen acidosis. 